\title{
APLIKASI RANTAI MARKOV PADA PREDIKSI HARI BERSALJU DI BEBERAPA KOTA AMERIKA SERIKAT
}

\author{
Rofiroh $^{1 *}$, Fika Dara Nurina Firdaus ${ }^{2}$, dan Salim² \\ ${ }^{1}$ Program Studi Teknik Mesin, Universitas Muhammadiyah Tangerang \\ Email: rofiroh@gmail.com \\ ${ }^{2}$ Program Studi Matematika, Institut Teknologi Bandung \\ J1. Ganesha No.10, Kota Bandung, Jawa Barat 40132
}

\begin{abstract}
This research is a stochastic process modeling. The method used is the Markov chain method with the stochastic process where the forthcoming condition $X_{t+1}$ will only be influenced by the closest preceding condition $X_{t}$. This method was applied to the observational data snow day for the Markov chain at eight observation stations in the United States, i.e the New York, Sedro Wooley, Glendive Willow City, Del Norte, Medford, Charleston, and Blue Hill. The purpose of this study is to determine the convergence direction of the $n$ step transition probability and the probability distribution of the Markov chain in three conditions. According to the results of data processing using Matlab software, diagonal matrices, and spectral theorems, similar results were obtained on the convergence of the transition matrix of each observation station which was influenced by the difference in probability changes of two conditions.
\end{abstract}

Keywords: Markov chain, snow day, transition matrix

\begin{abstract}
ABSTRAK
Penelitian ini merupakan pemodelan proses stokastik. Metode penelitian yang digunakan adalah metode rantai markov, dimana yang akan datang $X_{t+1}$ hanya akan dipengaruhi keadaan terdekat sebelumnya $X_{t}$. Metode ini diterapkan pada data pengamatan hari bersalju untuk rantai markov di delapan stasiun pengamatan yang ada di Amerika Serikat, yaitu stasiun pengamatan New York, Sedro Wooley, Glendive, Willow City, Del Norte, Medford, Charleston, dan Blue Hill. Tujuan penelitian ini adalah untuk mengetahui arah kekonvergenan peluang transisi dan menentukan distribusi peluang rantai markov $n$ langkah dengan tiga keadaan. Berdasarkan hasil pengolahan data dengan menggunakan software Matlab, matriks diagonal, dan teorema spektral didapatkan hasil yang sama untuk kekonvergenan matriks transisi dari masing-masing stasiun pengamatan dimana hasil tersebut dipengaruhi oleh selisih perubahan peluang dua keadaan.
\end{abstract}

Kata kunci: Rantai Markov, hari bersalju, matriks transisi 


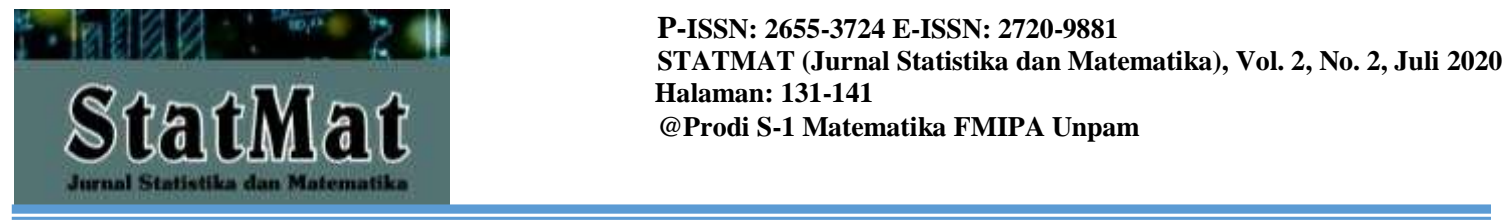

1. PENDAHULUAN

Banyaknya informasi misalnya data curah hujan, suhu harian maksimun, cuaca, dan harga saham yang bisa diakses oleh semua orang. Hal ini memudahkan kita dalam menganalisis dan memprediksi perubahan barisan informasi tersebut. Perubahan ini sangat bervariasi, ada perubahan yang bersifat statis namun ada juga yang bersifat dinamis. Perubahan yang terjadi memang tidak bisa dihindari. Seringkali perubahan berimbas pada sebuah kerugian. Oleh karena itu, sebaiknya dilakukan persiapan untuk sebuah perubahan. Setiap transisi yang terjadi dari waktu ke waktu perlu dicermati dengan baik. Salah satu solusi yang relevan untuk situasi tersebut adalah dengan melakukan prediksi yang terjadi di masa yang akan datang dengan proses markov.

Rantai Markov merupakan proses stokastik dimana distribusi bersyarat dari keadaan yang akan datang hanya dipengaruhi oleh keadaan terdekat sebelumnya. Rantai Markov seringkali digunakan untuk memodelkan barisan observasi dan mempelajari bagaimana perubahan akan terjadi pada masa yang akan datang. Rotondi (2010) meneliti salah satu aplikasi rantai Markov untuk memprediksi hari bersalju. Hari bersalju pada Penelitian Rotondi (2010) didefinisikan sebagai hari dimana ketebalan salju di tanah setidaknya $50 \mathrm{~mm}$ sedangkan hari tidak bersalju didefinisikan sebagai hari dimana ketebalan salju di tanah kurang dari $50 \mathrm{~mm}$.

Pengamatan pada penelitian ini difokuskan pada pengamatan terhadap kondisi ketebalan salju pada besok hari dimana telah diketahui kondisi ketebalan salju pada hari ini. Pengamatan dilakukan selama dua minggu terakhir bulan Desember, yang bertepatan dengan akhir tahun dan liburan Natal. Objek penelitian adalah delapan stasiun cuaca nasional pusat kota besar diantaranya, yaitu stasiun di dekat daerah Seattle, Denver, Milwaukee, Chicago, New York, Boston, Montana dan North Dakota. Berdasarkan kondisi di atas, hari bersalju di delapan stasiun Amerika Serikat dimodelkan dengan rantai markov. Hal ini dilakukan untuk memprediksi kondisi ketebalan salju yang akan datang

\section{DATA DAN METODOLOGI PENELITIAN}

\subsection{Data Penelitian}

Penelitian ini menggunakan data yang berasal dari data base Global Historical Climatology Network (GHCN 2010) berupa data ketebalan salju mulai tanggal 17 Desember hingga 31 Desember dengan tahun awal pengamatan dapat dilihat pada Tabel 1.

Tabel 1 Letak Geografis Stasiun Pengamatan

\begin{tabular}{ccccc}
\hline $\begin{array}{c}\text { Stasiun } \\
\text { Pengamatan }\end{array}$ & Lokasi & $\begin{array}{c}\text { Garis } \\
\text { Lintang }\end{array}$ & $\begin{array}{c}\text { Garis } \\
\text { Bujur }\end{array}$ & $\begin{array}{c}\text { Tahun Awal } \\
\text { Pengamatan } \\
\text { Ketebalan } \\
\text { Salju }\end{array}$ \\
\hline USC00305801 & New York (NY) & $40,78^{\circ}$ & $-73,97^{\circ}$ & 1912 \\
USC00457505 & Sendro Wooley (SW) & $48,50^{\circ}$ & $-122,23^{\circ}$ & 1898 \\
USC00243581 & Glendive (G) & $47,10^{\circ}$ & $-104,72^{\circ}$ & 1933 \\
USC00329445 & Willow City (WC) & $48,60^{\circ}$ & $-100,28^{\circ}$ & 1935 \\
USC00052184 & Del Norte (DN) & $37,67^{\circ}$ & $-106,32^{\circ}$ & 1938 \\
USC00475255 & Medford (M) & $45,13^{\circ}$ & $-90,35^{\circ}$ & 1889 \\
\hline
\end{tabular}




\begin{tabular}{lllll}
\hline P-ISSN: 2655-3724 E-ISSN: 2720-9881 \\
STATMAT (Jurnal Statistika dan Matematika), Vol. 2, No. 2, Juli 2020 \\
@alaman: 131-141 \\
@Prodi S-1 Matematika FMIPA Unpam
\end{tabular}

Sumber: Rotondi dan Michael A (2010)

Lokasi dari masing-masing stasiun pengamatan dapat dilihat pada Gambar 1.

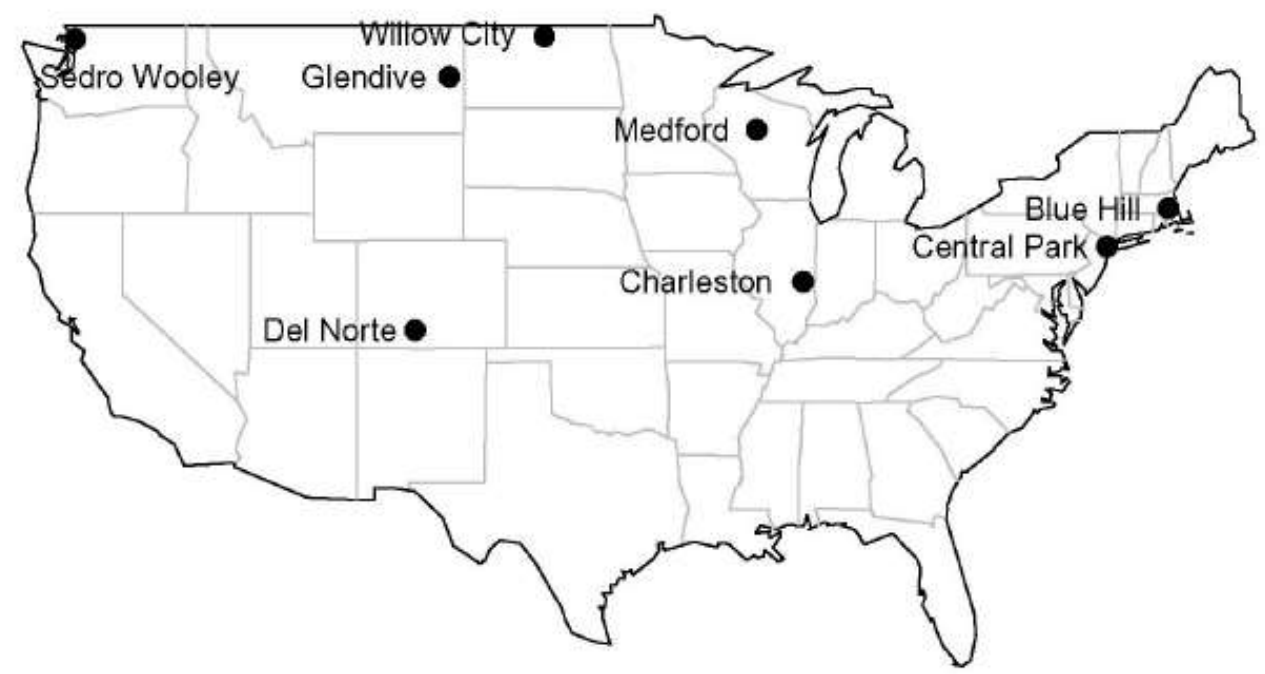

Gambar 1. Peta Lokasi Stasiun Pengamatan

Sumber: Rotondi dan Michael A (2010)

\subsection{Metodologi Penelitian}

Penelitian ini melakukan pemodelan pada proses stokastik hari bersalju atau tidak dengan menggunakan matriks transisi. Pengolahan matriks transisi menggunakan software Matlab, matriks diagonal dan teorema spcktral. Pengolahan data matriks transisi menggunakan software Matlab dilakukan dengan perhitungan matriks transisi tiga keadaan. Pada penelitian ini, keadaan $0\left(X_{t}=0\right)$ adalah ketebalan salju atau disimbolkan (KS) yang diamati pada waktu $t$ kurang dari $50 \mathrm{~mm}$. Kemudian, keadaan $1\left(X_{t}=1\right)$ dengan ketebalan salju (KS) yang diamati pada waktu $t$ setidaknya $50 \mathrm{~mm}$ dan kurang dari $100 \mathrm{~mm}$. Sedangkan keadaan $2\left(X_{t}=2\right)$, jika ketebalan salju (KS) yang diamati pada waktu $t$ setidaknya 100 $\mathrm{mm}$. Peluang transisi untuk pengamatan dengan tiga keadaan tersebut dapat dilihat pada Tabel 2. 


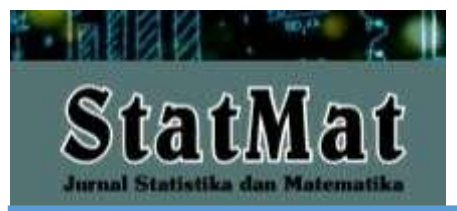

P-ISSN: 2655-3724 E-ISSN: 2720-9881

STATMAT (Jurnal Statistika dan Matematika), Vol. 2, No. 2, Juli 2020

Halaman: 131-141

@Prodi S-1 Matematika FMIPA Unpam

Tabel 2 Peluang Transisi dengan Tiga Keadaan

\begin{tabular}{ccccc} 
& & & \\
BSS $<50$ & $50 \leq \mathrm{KS}<100$ & $\mathrm{KS} \geq 100$ & Jumlah \\
\hline $\mathrm{KS}<50$ & $P_{00}$ & $P_{01}$ & $P_{02}$ & 1 \\
$50 \leq \mathrm{KS}<100$ & $P_{10}$ & $P_{11}$ & $P_{12}$ & 1 \\
$\mathrm{KS} \geq 100$ & $P_{20}$ & $P_{21}$ & $P_{22}$ & 1 \\
\hline
\end{tabular}

Matriks peluang transisi satu langkah $P_{i j}$ dengan $i, j=0,1,2$ dapat dituliskan dalam bentuk matriks berikut.

$$
P=\left[\begin{array}{lll}
p_{00} & p_{01} & p_{02} \\
p_{10} & p_{11} & p_{12} \\
p_{20} & p_{21} & p_{22}
\end{array}\right]
$$

dengan $P_{i j}$ adalah peluang transisi dari keadaan $i$ ke keadaan $j$ (Ross, 2003).

Analisis data dengan matriks transisi $n$ langkah menggunakan matriks diagonal. Menurut Horn dan Johnson (2013), matriks diagonal diperoleh melalui perhitungan pangkat suatu matriks transisi satu langkah. Misalkan $P$ dan $D$ masing-masing adalah matriks transisi satu langkah dan matriks diagonal. Kemudian, $\mathrm{H}$ adalah matriks yang dapat diinverskan sehingga matriks transisi $n$ langkah,

$$
P^{n}=H D^{n} H^{-1}
$$

dengan $n$ adalah bilangan bulat positif sebarang.

Analisis data pada tahap akhir adalah dengan matriks transisi menggunakan teorema spektral. Misalkan $P_{01}$ peluang transisi dari keadaan 0 ke keadaan $1 . P_{10}$ adalah peluang transisi dari keadaan 1 ke keadaan 0. Matriks transisi dengan satu langkah untuk dua keadaan diberikan sebagai berikut.

$$
P=\left[\begin{array}{cc}
1-p_{01} & p_{01} \\
p_{10} & 1-p_{10}
\end{array}\right]
$$

maka matriks transisi $n$ langkah dengan $n$ adalah bilangan positif sebarang,

$$
P^{n}=\frac{1}{p_{01}+p_{10}}\left[\begin{array}{ll}
p_{10} & p_{10} \\
p_{01} & p_{01}
\end{array}\right]+\frac{\left(1-p_{01}-p_{10}\right)^{n}}{p_{01}+p_{10}}\left[\begin{array}{cc}
p_{01} & -p_{10} \\
-p_{01} & p_{10}
\end{array}\right]
$$

\section{HASIL DAN PEMBAHASAN}

\subsection{Analisis Matriks transisi dengan menggunakan software Matlab}

Diagram transisi satu langkah dengan tiga keadaan untuk Kota Sedro Wooley dapat dilihat pada Gambar 2. 


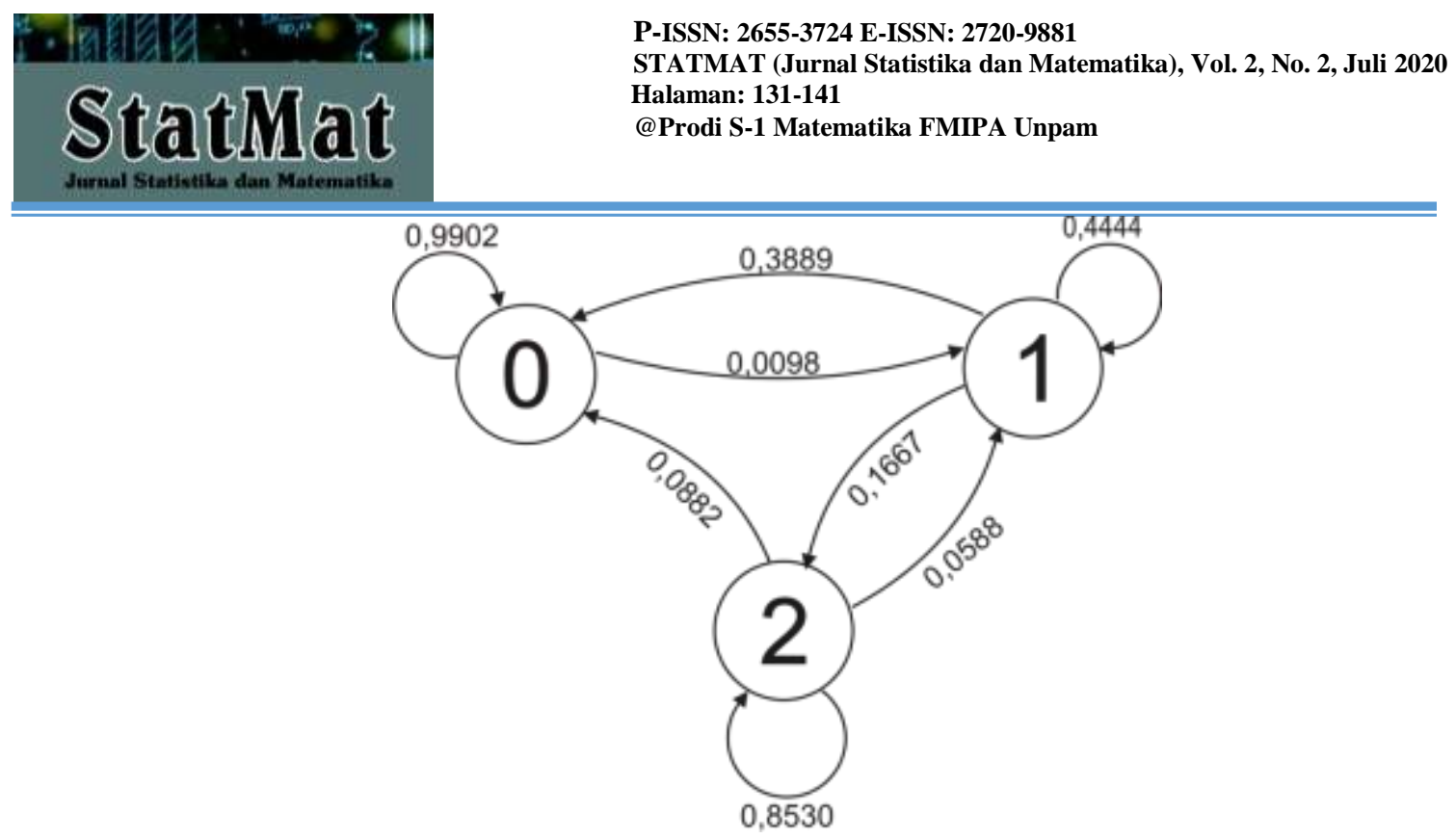

\section{Gambar 2. Diagram Transisi Dengan Tiga Keadaan}

Perhitungan matriks transisi dua dan tiga keadaan dengan $n$ langkah dapat dilihat pada Tabel 3.

Tabel 3 Matriks Transisi Dua dan Tiga Keadaan $\boldsymbol{n}$ Langkah untuk Setiap Stasiun Pengamatan

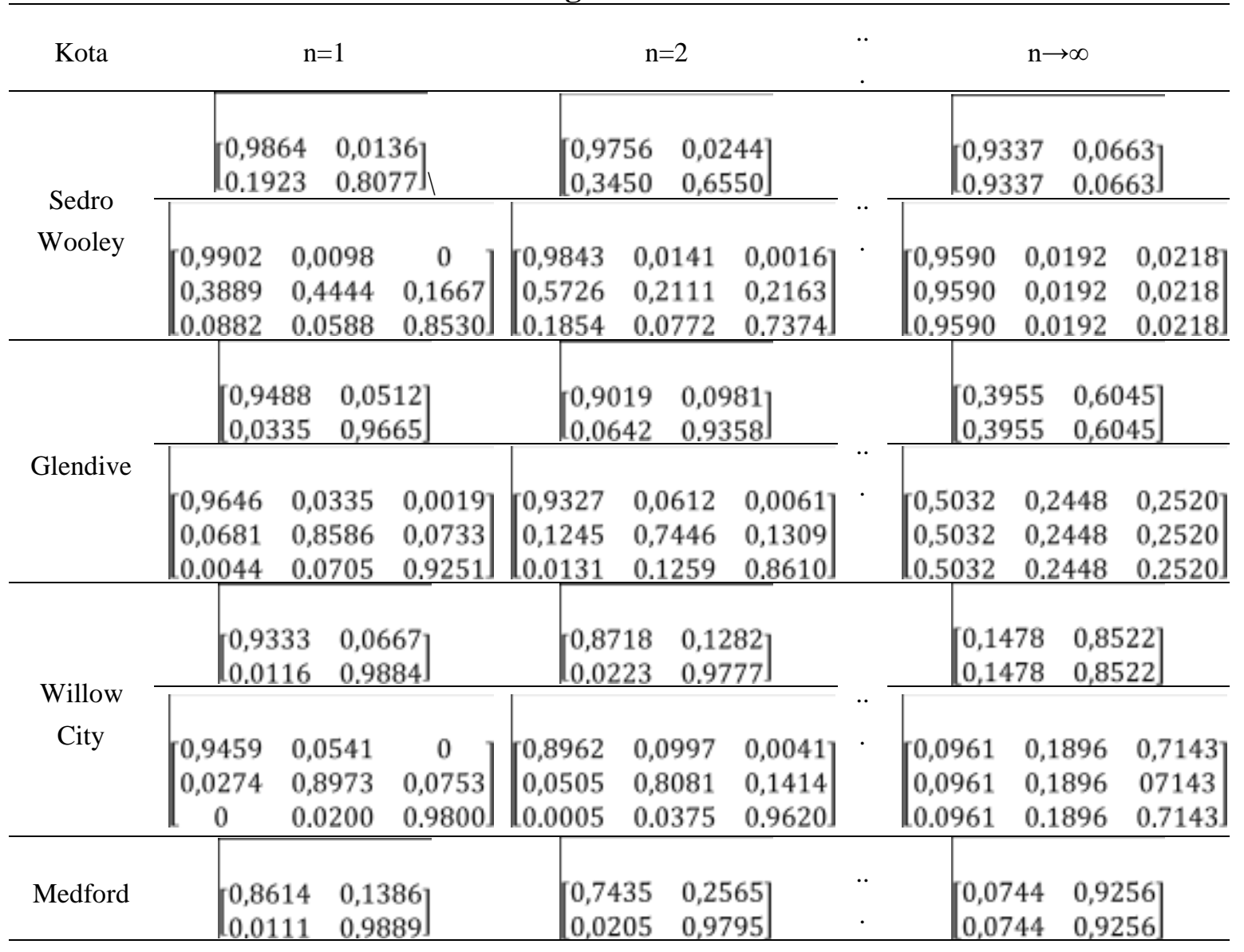




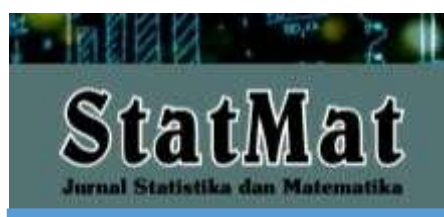

P-ISSN: 2655-3724 E-ISSN: 2720-9881

STATMAT (Jurnal Statistika dan Matematika), Vol. 2, No. 2, Juli 2020

Halaman: 131-141

@Prodi S-1 Matematika FMIPA Unpam

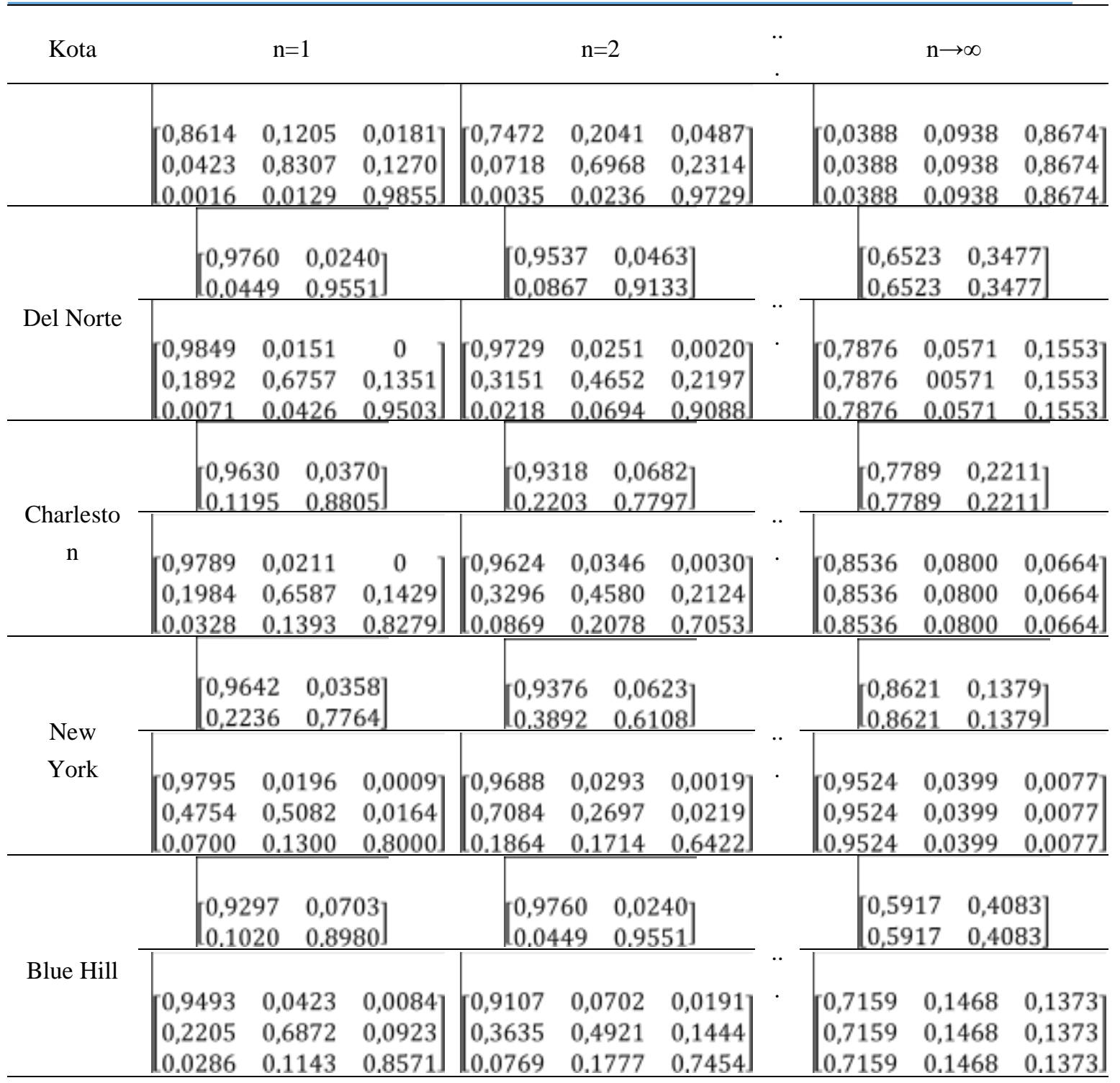

\subsection{Analisis matriks transisi dengan matriks diagonal}

Perhatikan matriks transisi pada keadaan awal di lokasi Sedro Wooley

$P=\left[\begin{array}{ccc}0,9902 & 0,0098 & 0 \\ 0,3889 & 0,4444 & 0,1667 \\ 0,0882 & 0,0588 & 0,8530\end{array}\right]$,

Dari matriks di atas diperoleh nilai eigen $\lambda_{1}=1, \lambda_{2}=0,8717$, dan $\lambda_{3}=0,4159$, matriks $\mathrm{H}$ yang kolom-kolomnya berisi vektor-verkor basis dan D matriks diagonal yang merupakan nilai eigen dari $\mathrm{P}$ 


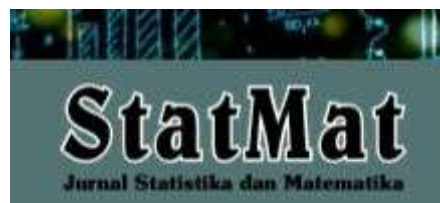

$\mathrm{H}=\left[\begin{array}{ccc}0,5774 & 0,0282 & 0,0169 \\ 0,5774 & -0,3409 & -0,9914 \\ 0.5774 & -0.9397 & 0.1299\end{array}\right], \quad \mathrm{D}=\left[\begin{array}{ccc}1 & 0 & 0 \\ 0 & 0,8717 & 0 \\ 00 & 0 & 0,4159\end{array}\right]$.

Sehingga,

$\mathrm{P}^{2}=\mathrm{HD}^{2} \mathrm{H}^{-1}$

$\mathrm{P}^{2}=\left[\begin{array}{ccc}0,5774 & 0,0282 & 0,0169 \\ 0,5774 & -0,3409 & -0,8814 \\ 0.5774 & -0.9397 & 0.1299\end{array}\right] \cdot\left[\begin{array}{ccc}1^{2} & 0 & 0 \\ 0 & 0,8717^{2} & 0 \\ 00 & 0 & 0.4159^{2}\end{array}\right] \cdot\left[\begin{array}{ccc}0,5774 & 0,0282 & 0,0169 \\ 0,5774 & -0,3409 & -0,8814 \\ 0.5774 & -0.9397 & 0.1299\end{array}\right]$

$P^{2}=\left\lfloor\left[\begin{array}{lll}0,9843 & 0,0141 & 0,0016 \\ 0,5726 & 0,2111 & 0,2163 \\ 0.1854 & 0.0772 & 0.7374\end{array}\right]\right.$.

Untuk $\mathrm{n} \rightarrow \infty$, maka

$$
\lim _{x \rightarrow \infty} P^{n}=\left[\begin{array}{lll}
0,9590 & 0,0192 & 0,0218 \\
0,9590 & 0,0192 & 0,0218 \\
0,9590 & 0,0192 & 0,0218
\end{array}\right] .
$$

Distribusi peluang rantai Markov dapat ditentukan dengan $n$ langkah dengan terlebih dahulu dicari vektor baris dari distribusi peluang keadaan awal dari rantai Markov $\left(\pi^{(0)}\right)$ tersebut.

1) Ketebalan salju kurang dari $50 \mathrm{~mm}$ sehingga keadaan awal dari rantai Markov $\pi^{(0)}=\left(\begin{array}{lll}1 & 0 & 0\end{array}\right)$, maka distribusi peluang rantai Markov dengan 73 langkah adalah

$$
\pi^{(73)}=\left(\begin{array}{lll}
0,9590 & 0,0192 & 0,0218
\end{array}\right)
$$

2) Apabila masing masing keadaan memiliki peluang yang sama sehingga $\pi^{(0)}=\left(\begin{array}{ccc}\frac{1}{3} & \frac{1}{3} & \frac{1}{3}\end{array}\right)$, maka distribusi peluang rantai Markov dengan 73 langkah adalah

$$
\pi^{(73)}=\left(\begin{array}{lll}
0,9590 & 0,0192 & 0,0218
\end{array}\right) \text {. }
$$

3) Apabila $\pi^{(0)}=\left(\begin{array}{lll}\frac{2}{6} & \frac{1}{6} & \frac{3}{6}\end{array}\right)$, maka distribusi peluang rantai Markov setelah 73 langkah adalah

$$
\pi^{(73)}=\left(\begin{array}{lll}
0,9590 & 0,0192 & 0,0218
\end{array}\right) .
$$




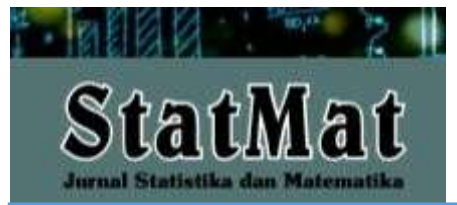

P-ISSN: 2655-3724 E-ISSN: 2720-9881

STATMAT (Jurnal Statistika dan Matematika), Vol. 2, No. 2, Juli 2020

Halaman: 131-141

@Prodi S-1 Matematika FMIPA Unpam

Matriks transisi satu langkah dan kekonvergenan dari matriks transisi pada stasiun lain dapat dilihat pada Tabel 4.

Tabel 4 Matriks Transisi Untuk Tiga Keadaan dan Kekonvergenannya

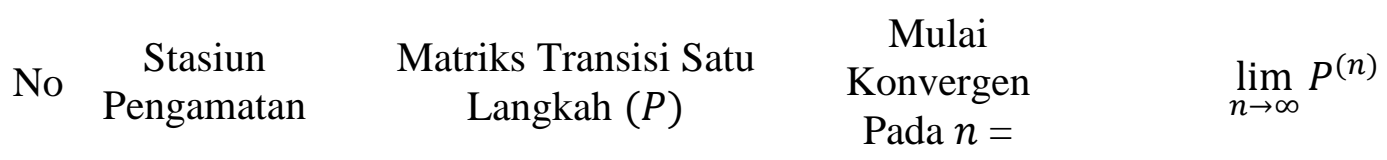

\begin{tabular}{|c|c|c|c|c|c|c|c|c|}
\hline \multirow{3}{*}{1} & & $(0,9902$ & 0,0098 & 0 & \multirow{3}{*}{73} & $(0,9590$ & 0,0192 & $0,0217)$ \\
\hline & & 0,3889 & 0,4444 & 0,1667 & & 0,9590 & 0,0192 & 0,0218 \\
\hline & & 0,0882 & 0,0588 & 0,8529 ( & & $(0,9590$ & 0,0192 & $0,0218)$ \\
\hline & & $(0,9647$ & 0,0335 & $0,0019>$ & \multirow{3}{*}{173} & 0,5032 & 0,2448 & 0,2520 \\
\hline \multirow[t]{2}{*}{2} & Glendive & 0,0681 & 0,8586 & 0,0733 & & 0,5032 & 0,2448 & 0,2521 \\
\hline & & $\backslash 0,0044$ & 0,0705 & (0,9251 & & 0,5031 & 0,2448 & 0,2521) \\
\hline \multirow{4}{*}{3} & & $(0,9459$ & 0,0541 & $0 \quad$ & & $(0,0961$ & 396 & $0,7142)$ \\
\hline & Wrilow & 0,0274 & 0,8973 & 0,0753 & \multirow[t]{3}{*}{242} & 0,0961 & 0,1896 & 0,7143 \\
\hline & & 0 & 0,0200 & $0,9800 /$ & & 0,0961 & 0,1896 & 0,7143) \\
\hline & & (0,8614 & 0,1205 & $0,0181)$ & & (0,0388 & 0,0938 & $0,8674)$ \\
\hline \multirow[t]{3}{*}{4} & Medford & 0,0423 & 0,8307 & 0,1270 & \multirow[t]{3}{*}{112} & 0,0388 & 0,0938 & 0,8674 \\
\hline & & 0,0016 & 0,0129 & 0,9855 ) & & 0,0388 & 0,0938 & $0,8674)$ \\
\hline & & 0,9849 & 0,0151 & 0 & & (0,7876 & 0,0571 & $0,1553)$ \\
\hline \multirow[t]{2}{*}{5} & Del Norte & 0,1892 & 0,6757 & 0,1351 & \multirow[t]{2}{*}{301} & 0,7876 & 0,0571 & 0,1553 \\
\hline & & $\begin{array}{l}0,0071 \\
10,9789\end{array}$ & $\begin{array}{l}0,0426 \\
0,0211\end{array}$ & $\begin{array}{c}0,9504 \\
0\end{array}$ & & $\begin{array}{l}0,7876 \\
0,8536\end{array}$ & & $\begin{array}{l}0,1553) \\
0,0664\end{array}$ \\
\hline \multirow[t]{3}{*}{6} & Charleston & 0,1984 & 0,6587 & 0,1429 & \multirow[t]{3}{*}{99} & 0,8536 & 0,0800 & 0,0664 \\
\hline & & $\backslash 0,0328$ & 0,1393 & (0,8279 & & 0,8536 & 0,0800 & 0,0664 ) \\
\hline & & $(0,9795$ & 0,0196 & $0,0009)$ & & 0,9524 & 99 & 0,0077 \\
\hline \multirow[t]{2}{*}{7} & New York & 0,4754 & 0,5082 & 0,0164 & \multirow[t]{2}{*}{47} & 0,9524 & 0,0399 & 0,0077 \\
\hline & & \0,0700 & & 0,8000 & & $\backslash 0,9524$ & 0,0399 & 0,0077) \\
\hline \multirow{2}{*}{8} & Blue Hill & 0.2205 & 0.6872 & 0.0923 & \multirow{2}{*}{78} & 0.7159 & 0.1468 & 0,1372 \\
\hline & & $(0,0286$ & 0,1143 & $0,8571)$ & & 0,7159 & 0,1468 & 0,1372 \\
\hline
\end{tabular}

Sementara itu, distribusi peluang dengan $n$ langkah untuk kedelapan stasiun pengamatan dapat dilihat pada Tabel 5.

Tabel 5 Distribusi Peluang Rantai Markov dengan $\boldsymbol{n}$ Langkah 


\begin{tabular}{|c|c|c|c|c|}
\hline \multicolumn{2}{|c|}{ 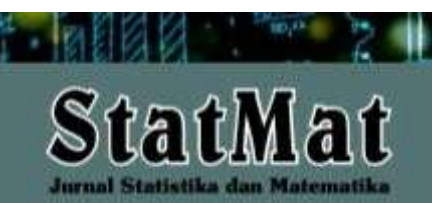 } & \multicolumn{3}{|c|}{$\begin{array}{l}\text { P-ISSN: 2655-3724 E-ISSN: 2720-9881 } \\
\text { STATMAT (Jurnal Statistika dan Matematika), Vol. 2, No. 2, Juli } 2020 \\
\text { Halaman: 131-141 } \\
\text { @Prodi S-1 Matematika FMIPA Unpam }\end{array}$} \\
\hline & & & $\pi=P^{(n)} P_{0}$ & \\
\hline Pengamatan & $n$ & $P_{0}=\left(\begin{array}{lll}1 & 0 & 0\end{array}\right)$ & $P_{0}=\left(\begin{array}{lll}\frac{1}{3} & \frac{1}{3} & \frac{1}{3}\end{array}\right)$ & $P_{0}=\left(\begin{array}{lll}\frac{2}{6} & \frac{1}{6} & \frac{3}{6}\end{array}\right)$ \\
\hline Sedro Wooley & 73 & $\left(\begin{array}{l}0,9591 \\
0,0192 \\
0,0217\end{array}\right)^{t}$ & $\left(\begin{array}{l}0,9590 \\
0,0192 \\
0,0218\end{array}\right)^{t}$ & $\left(\begin{array}{l}0,9590 \\
0,0192 \\
0,0218\end{array}\right)^{t}$ \\
\hline Glendive & 173 & $\left(\begin{array}{l}0,5032 \\
0,2448 \\
0,2520\end{array}\right)^{t}$ & $\left(\begin{array}{l}0,5032 \\
0,2448 \\
0,2520\end{array}\right)^{t}$ & $\left(\begin{array}{l}0,5032 \\
0,2448 \\
0,2521\end{array}\right)^{t}$ \\
\hline Willow City & 242 & $\left(\begin{array}{l}0,0961 \\
0,1896 \\
0,7142\end{array}\right)^{t}$ & $\left(\begin{array}{l}0,0961 \\
0,1896 \\
0,7143\end{array}\right)^{t}$ & $\left(\begin{array}{l}0,0961 \\
0,1896 \\
0,7143\end{array}\right)^{t}$ \\
\hline Medford & 112 & $\left(\begin{array}{l}0,0388 \\
0,0938 \\
0,8674\end{array}\right)^{t}$ & $\left(\begin{array}{l}0,0388 \\
0,0938 \\
0,8674\end{array}\right)^{t}$ & $\left(\begin{array}{l}0,0388 \\
0,0938 \\
0,8674\end{array}\right)^{t}$ \\
\hline Del Norte & 301 & $\left(\begin{array}{l}0,7876 \\
0,0571 \\
0,1553\end{array}\right)^{t}$ & $\left(\begin{array}{l}0,7876 \\
0,0571 \\
0,1553\end{array}\right)^{t}$ & $\left(\begin{array}{l}0,7876 \\
0,0571 \\
0,1553\end{array}\right)^{t}$ \\
\hline Charleston & 99 & $\left(\begin{array}{l}0,8536 \\
0,0800 \\
0,0664\end{array}\right)^{t}$ & $\left(\begin{array}{l}0,8536 \\
0,0800 \\
0,0664\end{array}\right)^{t}$ & $\left(\begin{array}{l}0,8536 \\
0,0800 \\
0,0664\end{array}\right)^{t}$ \\
\hline New York & 47 & $\left(\begin{array}{l}0,9523 \\
0,0399 \\
0,0077\end{array}\right)^{t}$ & $\left(\begin{array}{l}0,9523 \\
0,0399 \\
0,0077\end{array}\right)^{t}$ & $\left(\begin{array}{l}0,9523 \\
0,0399 \\
0,0077\end{array}\right)^{t}$ \\
\hline Blue Hill & 78 & $\left(\begin{array}{l}0,7159 \\
0,1468 \\
0,1372\end{array}\right)^{t}$ & $\left(\begin{array}{l}0,7159 \\
0,1468 \\
0,1372\end{array}\right)^{t}$ & $\left(\begin{array}{l}0,7159 \\
0,1468 \\
0,1372\end{array}\right)^{t}$ \\
\hline
\end{tabular}

\subsection{Analisis matriks transisi dengan menggunakan teorema spektral}

Perhatikan matriks transisi pada keadaan awal di lokasi Sedro Wooley

$$
\left[\begin{array}{ll}
0,9864 & 0,0136 \\
0,1923 & 0,8077
\end{array}\right] \text {. }
$$

Maka nilai

$$
P=\left(\begin{array}{cc}
1-0,0136 & 0,0136 \\
0,1923 & 1-0,1923
\end{array}\right)
$$

dan matriks transisi dengan $n$ langkah adalah 


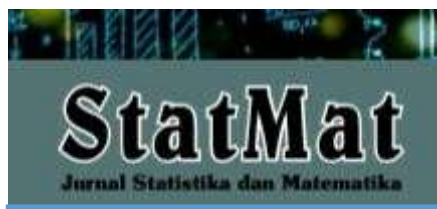

P-ISSN: 2655-3724 E-ISSN: 2720-9881

STATMAT (Jurnal Statistika dan Matematika), Vol. 2, No. 2, Juli 2020

Halaman: 131-141

@Prodi S-1 Matematika FMIPA Unpam

$$
\begin{aligned}
& P^{73}=\frac{1}{0,0136+0,1923}\left(\begin{array}{ll}
0,1923 & 0,1923 \\
0,0136 & 0,0136
\end{array}\right)+\frac{(1-0,0136-0,1923)^{73}}{0,0136+0,1923}\left(\begin{array}{cc}
0,0136 & -0,1923 \\
-0,0136 & 0,1923
\end{array}\right) \\
& =\left[\begin{array}{ll}
0,9337 & 0,0663 \\
0,9337 & 0,0663
\end{array}\right]
\end{aligned}
$$

Matriks transisi dengan $n$ langkah untuk kedelapan stasiun pengamatan dapat dilihat pada Tabel 6.

\section{Tabel 6 Matriks transisi dengan $\boldsymbol{n}$ langkah untuk kedelapan stasiun pengamatan}

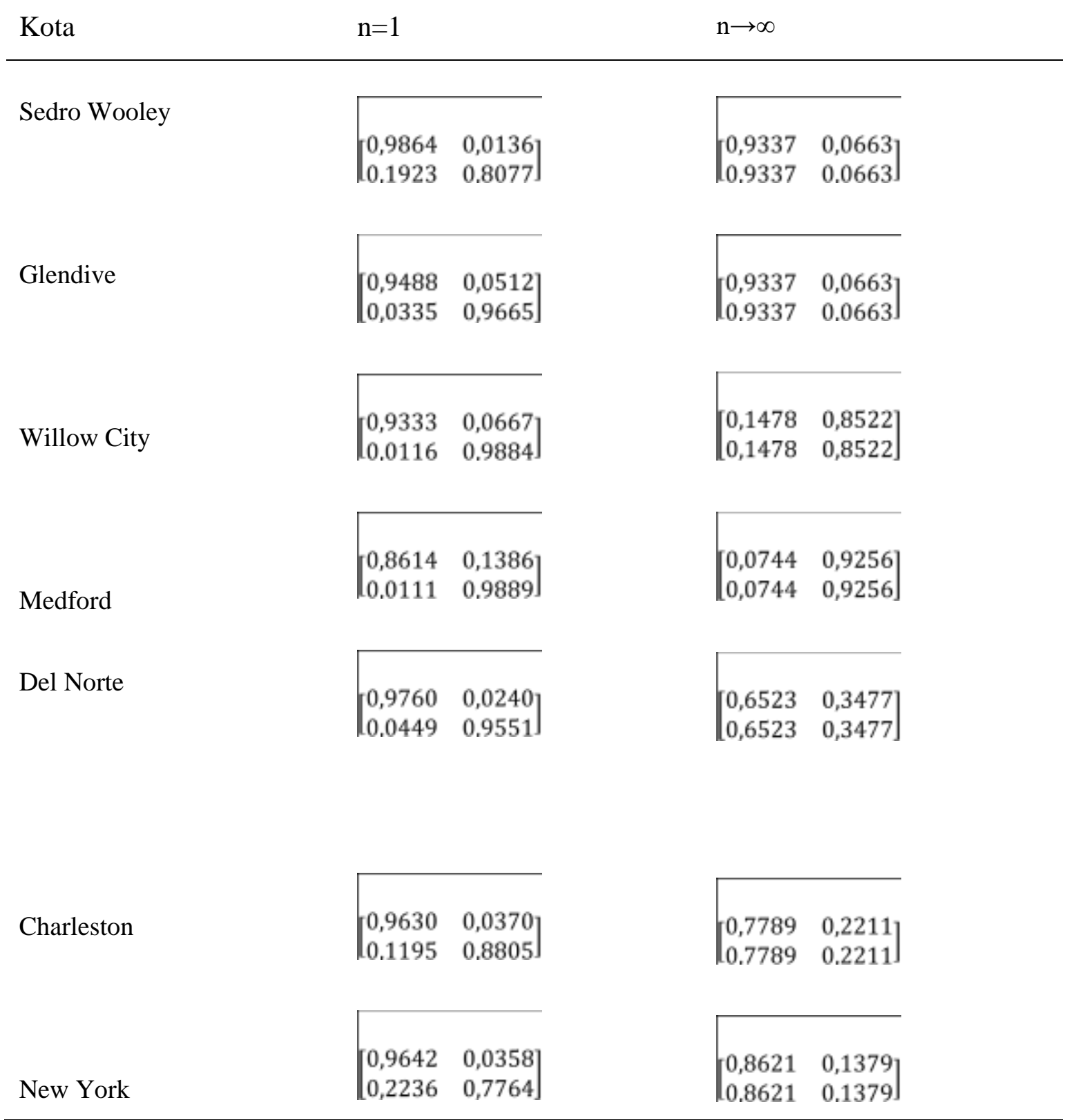


Blue Hill

$\left.\begin{array}{ll}\hline 0,9297 & 0,0703 \\ 0.1020 & 0.8980\end{array}\right] \quad\left[\begin{array}{ll}0,5917 & 0,4083 \\ 0,5917 & 0,4083\end{array}\right]$

\section{SIMPULAN}

Berdasarkan perhitungan dengan menggunakan software Matlab, matriks diagonal, dan teorema spektral didapatkan hasil yang sama untuk matriks transisi pada saat $n \rightarrow \infty$. Arah kekonvergenan matriks transisi untuk masing-masing stasiun pengamatan dipengaruhi oleh selisih perubahan peluang dua keadaan.

\section{DAFTAR PUSTAKA}

GHCN. 2010. Global historical climate network. Tersedia pada http://www1.ncdc.noaa.gov/pub/data/ghcn/daily

Horn, R.A., Johnson, C. R. 2013. Matrix Analysis. New York: Cambridge University Press. Ross, Sheldon M. 2003. Stochastic Process Second Edition. United States of America: John Wiley \& Sons, Ink.

Rotondi, Michael A. 2010. To Ski or Not to Ski: Estimating Transition Matrices to Predict Tomorrow's Snowfall Using Real Data. Journal of Statistics Education, Volume 18, Number 3. 